\title{
Book Review: Kenneth M. Cuno, Modernizing Marriage: Family, Ideology, and Law in Nineteenth- and Early Twentieth-Century Egypt.
}

\section{Citation}

Najmabadi, Afsaneh. 2016. “Kenneth M. Cuno, Modernizing Marriage: Family, Ideology, and Law in Nineteenth- and Early Twentieth-Century Egypt." The American Historical Review 121 (2) (April): 683-684. doi:10.1093/ahr/121.2.683.

\section{Published Version}

doi:10.1093/ahr/121.2.683

\section{Permanent link}

http://nrs.harvard.edu/urn-3:HUL.InstRepos:27531385

\section{Terms of Use}

This article was downloaded from Harvard University's DASH repository, and is made available under the terms and conditions applicable to Open Access Policy Articles, as set forth at http:// nrs.harvard.edu/urn-3:HUL.InstRepos:dash.current.terms-of-use\#OAP

\section{Share Your Story}

The Harvard community has made this article openly available.

Please share how this access benefits you. Submit a story.

\section{Accessibility}


Kenneth Cuno, Modernizing Marriage: Family, Ideology, and Law in Nineteenth- and Early Twentieth-Century Egypt. Syracuse: Syracuse University Press, 2015.

Kenneth Cuno's book is a most welcome addition to histories of the family in the Middle East. It builds on current historiographies, usually focused on transformations of family law or on emergence of companionate marriage as the new notion of the ideal family.

The preface opens with an anecdote that captures Cuno's central: "Khedive Ismail had multiple wives and concubines.... However, his grandson...practiced polygyny surreptitiously, like a man with a mistress in a legally monogamous society, even though polygyny remains legal in Egypt to this day." (p. xv) The overwhelming power of the idea of monogamy, by the turn of the twentieth century, had made it a culturally unacceptable practice even for the ruler of the country.

Cuno argues that "these hegemonic ideas ... have only a limited connection with Islamic concepts of an earlier time. ... The idea of the conjugal family as the basis of society comes from Enlightenment thought, as does the notion that the purpose of marriage is the formation of a family and childrearing." (2) Yet, he rightly resists any simple projection of the emerging hegemony of the ideal conjugal family as a colonial import. As he notes, "Ideological trends may have contributed the most to the decline of polygyny in the long run, but the transition to conjugal family households seems to have been caused by multiple factors, including the development of modern education, a rising age of marriage for both sexes, and the adoption of European architectural styles.” (p. 7)

In six chapters (with an Introduction and a Conclusion), Cuno traces the changes that contingently produced this socio-cultural shift. Chapter 1 is focused on political work of marriage for the Khedival governmental system: "Polygyny and harem slavery did 'political work' in the system of household government established by Muhammad 'Ali, founder of the khedival dynasty. ... The demise of household government, the end of the slave trade, and the adoption of monogamy by the khedival family are examples of how contingent political developments affected elite family culture. ... [T] he decline of polygyny and joint household formation in the upper and middle classes resulted from contingent political and demographic changes ... influenced by a new family ideology ... in global circulation of ideas about the family, education, and progress" (10-12)

Cuno sharply focuses on ideational power of the conjugal couple. He persuasively demonstrates how not only did the ideal marriage become a companionate marriage, but also, regardless of whether the newly married couple lived in a joint or in a separate household, the conjugal couple became the idealized meaning of family.

Cuno uses diverse sources to support his analytical propositions, including novels and memoirs, mid- to late-nineteenth century census data and village reports, and legal treatise - some of which have been used by previous historians. But Cuno's readings and interpretations offer fresh insights that further support his emphasis on contingent patterns of marriage practices and legal change within the emerging hegemony of the new ideal family. For instance, while it has generally been accepted that late-nineteenth- 
and early-twentieth-century novels were written in a style to produce the supremacy of love marriage, one does not see the same dynamic in the writings of the memoirists who advocated autonomy in spousal choice but did not emphasize love as the criterion for that choice. To the contrary, they continued to project the cultural expectation that affection among spouses would develop after marriage. Such disparities between the plot line of novels and the sub-plots of life remembered is critical in understanding how despite ideational hegemony of romantic monogamous marriage, practices of family life have developed in multiple patterns, and continue to be lived in varied combinations. Cuno uses memoirs effectively as a prime source for studying "Marriage in Practice" in chapter 2. As a source for "recollection of their sentiments," they demonstrate how polygyny lost its place in the new family ideology, how families negotiated for a monogamous contract, and in particular how women in the family asserted their expectations of a lasting companionate marriage. Indeed this change in expectation seems to have happened over a relatively short period: women whose mothers lived in polygynous households considered their husbands' polygynous practices intolerable. Cuno recalls Huda alSha'rawi's memoirs to this effect (pp. 51-52); the same sentiment is expressed in Halidé Edib's memoirs, House with Wisteria (Charlottesville, VA: Leopolis Press, 2003. With an Introduction by Sibel Erol) where she discusses the reason for her insistence on a divorce from her first husband in 1910, long before polygyny was outlawed in Turkey (1926), in such terms. Edib had grown up in an at-times polygynous household. But she had opted for a love-marriage, she explains. She had tolerated her husband's liaisons with other women, so long as these "other women" remained outside the conjugal family's frame. Her husband's decision to marry a second wife was simply not tolerable. (Edib, p. 253)

Cuno's use of family photographs is another welcome and persuasive move in tracing this history. The coincidence of changes in familial concepts and practices with arrival of photography in the Middle East gives the historian a very significant archival resource. Photography came to some of the urban centers of the Ottoman domains (and to Qajar Iran) shortly after its invention. Both the camera as an object, and the "family photographs," were among those objects of everyday life that generated changes in practices meanings of family. "Photos of married couples, not necessarily taken on the day of the wedding, also became popular around the turn of the twentieth century. Like the family tableau in Figure 2, they express a couple-centered notion of family." (69) As Cuno argues, "Regardless of whether they lived in a joint or conjugal family household, couples who posed for intimate photos ... presented themselves as bourgeois conjugal families." (p. 55) These photographs not only reflected the process of "ideationalization" of the conjugal couple; they in turn contributed to its power incessantly: these photographs were framed and displayed in the home in prominent places, on walls, on cupboards and bookshelves, or over pianos in more prosperous homes. Their ubiquitous visual presence -- one saw them everyday, one saw them in most urban middle class homes - contributed to the normative idealness of the conjugal couple.

Subsequent chapters ("Marriage Reformed," "Marriage in Law," "Marriage Codified," and "Marriage Modernized?") fully trace the developments in the ideas of family, the idealization of the conjugal couple and their children, linked with critique of polygyny 
and easy divorce for men as a source of social instability and erosion of civil sentiments; consequently, "The family became a subject of public discourse and government policy, including the invention of family law as a distinct category of law known as "personal status law"" (78) -- a term [al-ahwal al-shakhsiyya] that "was unknown in Muslim jurisprudence before the late nineteenth century." (165) Codification of family law as a separate and distinct legal category (out of its former placement within the book of all transactions, the mu'amilat, is a critical argument (developed in chapter 5). In particular, the decision to develop civil, commercial, and criminal laws on the basis of French law in Egypt, to be enacted through the establishment of National Courts, and separating family law to a separate domain and under separate courts, had enormous consequences: "Nowadays the association of religion with the domestic realm and the derivation of family law from religious law is taken for granted, but that is a consequence of the reorganization of the judicial system," as Cuno demonstrates. (pp. 159-160) His detailed discussion of Qadri's Code demonstrates wonderfully how the Code generated a family law that took its content from the Hanafi school while presenting it in the form of modern law articles: "The radically different form of Qadri's personal status code was due to its mimicking of the form of the French code. It was arranged in topical chapters and sections comprising 647 numbered articles. ... In contrast to the five thick tomes filled by Radd al-Muhtar, Qadri's code was a slim volume of 138 pages. ... [E]ach article in his code states a rule or a set of rules without any acknowledgment of the historical scholarship that led to its formulation. There was no hint that these rules resulted from generations of discussion and debate or that they might be subject to disagreement and revision in certain circumstances." (169) Thus: "Qadri's influential code of personal status, designed in the form of a European code, stated mainstream Hanafi legal norm as positive law and elided the historical discussion that produced them, including the variant opinions.” (187)

Despite such meticulous attention to detailed textual, organizational, and visual analysis, at times in Cuno's own narrative, one finds slippages among family ideology, family life, and family law, and at times the use of companionate marriage and monogamy as necessarily coincidental terms - demonstrating the weight of the hegemony of these ideas on all of us. Nonetheless, this book opens up fresh possibilities for further research on practices of family life beyond the power of hegemonic ideas. It is a must-read for not only historians of modern Middle East, but historians of family law and life more generally. 